\title{
The Role of the Spanish Armed Forces in the Fight against the Covid-19 Pandemic
}

\author{
Veronika HORNYÁK ${ }^{10}$
}

\begin{abstract}
Similarly to other European countries, the Spanish Government decided to take extensive measures against the spread of the Covid-19 virus in the country with the announcement of special legal order, curfews and the deployment of the armed forces. The 'Fuerzas Armadas Españolas', the FAS, have had an active role in the fight against the pandemic ever since executing a wide variety of tasks on a daily basis, including disinfecting critical infrastructure, and supporting the detection and the monitoring of infected citizens. Besides summarising the role of the Spanish Armed Forces in the fight against Covid-19 in the first year of the pandemic, the present paper explores other aspects of the deployment, such as civil-military relations and the attitude of the society towards military personnel.
\end{abstract}

Keywords: Spain, Spanish Armed Forces, Covid-19 pandemic, Operation Balmis, Mission Baluarte

\section{Introduction}

The Covid-19 epidemic reached Europe in less than 60 days following the first distant news release in the beginning of 2020, which subsequently forced European nations to their knees in just a few short weeks. For officially unknown reasons, the two largest European countries in the Mediterranean region, Italy and Spain, were affected earlier and more severely by the virus than other EU countries, especially during the first wave. The Kingdom of Spain, which has had a long-standing historical military tradition, responded to the outbreak of Covid-19 in March 2020 with one of the strictest measures in the EU, including curfew and other restrictions. This should not be surprising, as the pandemic claimed approximately 50,000 casualties in the country alone during 2020, the initial year of the outbreak. ${ }^{2}$ One possible reason for this high number of fatalities within EU nations was that, similarly to Italy, almost 20 per cent of the 47 million population of Spain was over the age of 65 , which caused a much higher mortality rate following infection by the virus. ${ }^{3}$ In response to the epidemic, the government enacted a special legal order in the

PhD student, University of Public Service Doctoral School of Military Sciences, e-mail: veronika.vhornyak@ gmail.com

2 Statista, 'Número total de personas fallecidas a causa del coronavirus en España entre el 6 de marzo y el 4 de diciembre de 2020', 2020.

3 The World Factbook, 'Spain', United States Central Intelligence Agency, 2020. 
country. During the second wave of the Covid-19, compared to the first one and to the situation in other European countries, the pandemic did not claim a significant number of casualties in Spain. Nevertheless, the events of Spring 2020, the shocking emergency during the first wave has fundamentally determined the Spanish attitude towards the epidemic, as well as the role of the Spanish Armed Forces in fighting the pandemic.

The role and tasks of the armed forces were not specified in detail, rather held as a special legal order in the relevant Spanish statute, ${ }^{4}$ thus, the conditions and circumstances of a possible deployment were based on the decisions of the actual political leadership, the government. The latter occurred accordingly regarding the outbreak of the coronavirus epidemic. Following the announcement by the World Health Organization on 11 March 2020 classifying Covid-19 as a pandemic, ${ }^{5}$ the Spanish Administration, led by Prime Minister Pedro Sánchez, ordered the establishment of a special legal order within a few days. On 14 March 2020, a state of emergency was announced in a royal decree, which was followed immediately by the launch of Operación Balmis, or Operation Balmis. ${ }^{6}$ The Spanish Armed Forces ${ }^{7}$ (henceforth: FAS) domestic epidemic control operation was the largest military operation in the country's history to date during peacetime. All branches of the FAS participated in the operation, with the basic task of assisting in the fight against the epidemic, including military patrolling, protecting, securing, and disinfecting hospitals and other critical infrastructure. ${ }^{8}$

This study aims to summarise the role of the Spanish Armed Forces based on mixed method research, with a brief examination of the relevant legal instruments connected to the special legal order, as well as the role, tasks and functions of the armed forces in domestic crisis management regarding the pandemic. The paper introduces the circumstances of the deployment of the FAS in the fight against Covid-19 in 2020, with special focus on the Operation Balmis and Mission Baluarte. Besides the research on the relevant statues and strategic documents of the Kingdom of Spain, other primer and secondary resources were used for the understanding of the topic, such as: government publications, statistics - including personnel and gender statistics - and communications particularly from the Spanish Ministry. Moreover, local and national press materials, as well as an outlook on social media supports the understanding of the civil-military aspects of the deployment of the Spanish Armed Forces in Operation Balmis and Mission Baluarte in the first year of the fight against Covid-19. The concluding chapter highlights several aspects of the changes that have taken place in connection with the use of the FAS members deployed in domestic measures involved in epidemiological control, with focusing on what conclusions can be drawn and directions of development can be forecasted as a consequence of the Operation Balmis and Mission Baluarte.

\footnotetext{
'Ley Orgánica 4/1981, de 1 día de junio, de los estados de alarma, excepción y sitio’.

World Health Organization, 'WHO Director-General's opening remarks at the media briefing on COVID-19', 11 March 2020.

6 Ministerio de Defensa, 'Reportajes: En primera línea’, 15 March 2020.

Fuerzas Armadas de España.

Ministerio de Defensa, 'Reportajes’.
} 


\section{The Spanish Armed Forces and the special legal order}

The Spanish Armed Forces have centuries-old traditions, dating back to the $15^{\text {th }}$ century, which would undoubtedly classify them as one of the European Union's top armies. ${ }^{9}$ Based on several indicators, such as defence budget, capabilities or the number of personnel, the Spanish Armed Forces ranked in the top 20 militaries in the world. ${ }^{10}$ This is still the case, despite the fact that Spain is one of only two of the NATO allies with Italy, which have had to reduce their defence budget percentage of their GDP share in recent years. ${ }^{11}$ The task and purpose of the Spanish Armed Forces were set out in Article 8 of the Spanish Constitution of 1978, according to which the purpose of the FAS is to protect the 'territorial integrity and constitutional order' of the Kingdom of Spain. ${ }^{12}$ The detailed conditions of its operation and deployment laid down in a number of organic laws, such as Act No. 9 of $2011^{13}$ on the rights and obligation of the members of the Spanish Armed Forces, and in other legal instruments, such as royal and/or government decrees, and decrees of the Ministry of Defence. ${ }^{14}$ An important example is the Royal Decree 416 of 2006 (11/04/2006) highlighting the organisation and the deployment of the Army, the Navy, the Air Force and the Military Emergency Unit ${ }^{15}$ (henceforth: UME). ${ }^{16}$ In the Spanish legal system, in case of an emergency by simplifying and shortening the ordinary legislative and decision-making procedure, the current political leadership could promulgate a special legal order to respond quickly to threatening emergencies. The provisions for such cases are primarily determined by two pieces of legislation: the Spanish Constitution ${ }^{17}$ and the Organic Law 1981/4. ${ }^{18}$ The latter differentiates between three types of special legal order situations possibly used in case of national emergency situations: 'estado de alarma' - state of alarm, ${ }^{19}$ 'estado de sitio' - state of siege, and 'estado de exepción' - state of emergency. ${ }^{20}$

Besides the relevant legal instruments, it is worth taking a brief look to a more political, strategic document, the Spanish National Security Strategy 2017, which was born under the previous administration led by Prime Minister Mariano Rajoy, from the Popular Party ${ }^{21}$ of Spain. ${ }^{22}$ The document does not mention epidemiological situations and pandemics as a direct threat to Spanish national security, but as a challenge 'to

\footnotetext{
Ministerio de Defensa, 'Ejército de Tierra', 2021.

Global Firepower, ‘2021 Military Strength Ranking’, 2021.

International Institute for Strategic Studies, The Military Balance 2020 (London: Routledge, 2021), 70.

‘Constitución Española', 1978.

'Ley Orgánica 9/2011, de 27 de julio, de derechos y deberes de los miembros de las Fuerzas Armadas'.

Ministerio de Defensa, 'Legislación', 2021.

Unidad Militar de Emergencias.

16 'Real Decreto 416/2006, de 11 de abril, por el que se establece la organización y el despliegue de la Fuerza del Ejército de Tierra, de la Armada y del Ejército del Aire, así como de la Unidad Militar de Emergencias’.

'Constitución Española', 1978.

'Ley Orgánica 4/1981, de 1 día de junio, de los estados de alarma, excepción y sitio’.

Presidencia del Gobierno, 'Estado de Alarma’, 2020.

'Ley Orgánica 4/1981, de 1 día de junio, de los estados de alarma, excepción y sitio’.

Partido Popular.

'Spanish National Security Strategy', 2017.
} 
be addressed' classified it to lower risk category. ${ }^{23}$ The strategy emphasises that the epidemiological and public health challenges, especially as a country attracting millions of tourists, deserve increasing attention as well as 'developed preparedness response plans for health threats and challenges, both generic and specific, with a multi-sector approach to ensure proper coordination of all the administrations involved'. ${ }^{24}$ However, in the event of an emergency due to a possible pandemic, the strategy does not mention explicitly the possibility of deploying the FAS, but with referring to 'border control', 'developed preparedness' and 'multi-sector approach', it envisaged the use of uniformed personnel in case of pandemics, not specifying whether it shall be police or military personnel. Accordingly, and to bridge the gap between strategy and operation, as well as directly responding to the epidemic situation, the Spanish National Defense Directive ${ }^{25}$ was born in 2020 replacing the previous one from 2012. The Directive explicitly highlights the Covid-19 pandemic and describes the deployment of FAS as follows: 'The Armed Forces are developing its permanent missions while regularly assisting civilian authorities in facing threats, frequently unconventional ones. The efforts to collaborate and support civilian authorities shall be maximized in handling crisis and emergency situations. ${ }^{26}$ The quoted part is one of the points of the Spanish National Defense Directive, which was formulated directly reflecting the Covid-19 epidemic, integrating the lessons of Operation Balmis, and paying special attention to the civilian-military cooperation and capacity building in this area. ${ }^{27}$

The Spanish Armed Forces ${ }^{28}$ - also referred to as Defence Staff in English - operating within the abovementioned theoretical, political and legal framework, is led by the commander-in-chief, who is the head of state, the Spanish monarch, currently King Felipe VI. Whereas civilian control is exercised by the Minister in charge of the Ministry of Defence through the actual government. The Minister of Defence, currently Margarita Robles Fernández since 2018, is also responsible for civilian control of the Armed Forces. ${ }^{29}$ The Chief of Defence Staff (CHOD) ${ }^{30}$ of the Spanish Armed Forces - a position equivalent to a secretary of state in Spain - is Admiral General Teodoro E López Calderón, General of the Spanish Navy since January 2020. ${ }^{31}$ The peculiarity of the Spanish Armed Forces is that, in addition to the presence of the three classical branches, the Air Force, the Navy and the Army, the Royal Guards - originally known as the Guardia Real - and already mentioned Military Emergency Unit (UME), is considered a joint special unit of the armed forces. ${ }^{32}$ As for the available military personnel, according to official statistics published by the Ministry of Defence in 2019, the FAS numbered a total of 145,417 soldiers, of which

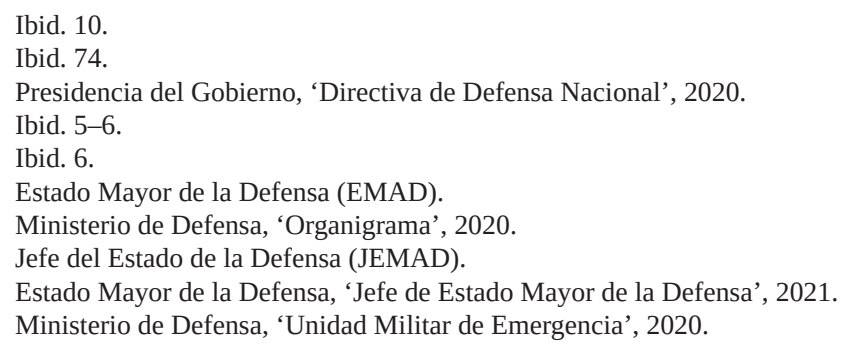


120,102 were in active service. ${ }^{33}$ Another specialty of the Spanish defence system is that the armed forces are supplemented by the so-called Guardia Civil, the Civil Guard, in which more than 80,000 personnel serve (together with the reserve personnel), and which operates in the military structure; however, it also performs law enforcement tasks. ${ }^{34}$ The duality of the status and purpose of the Guardia Civil is given by the fact that the Ministry of Defence has control over its personnel only in case of foreign deployment, such as NATO or EU-led missions and operations, but in all other cases, the Ministry of the Interior is the governing body of the Guardia Civil. ${ }^{35}$

The $20^{\text {th }}$ anniversary of the adoption of the landmark United Nations Security Council resolution, UNSCR 1325 (2000) on women, peace and security ${ }^{36}$ coincided with the outbreak of the Covid-19 pandemic in 2020. On this note, it is worth briefly mentioning the role of women in security and in the armed forces in Spain, which is also highlighted in the afore-mentioned National Defence Directive. ${ }^{37}$ The women, peace and security agenda, also known as the WPS agenda ${ }^{38}$ is at the forefront of the Spanish Government's policy on security and defence, in the framework of inter-ministerial cooperation. ${ }^{39}$ Spain is one of those few countries globally where the position of the minister of defence has been held repeatedly by women. However, regarding the gender statistics of the Spanish Armed Forces, there is room for further improvement, which was highlighted at political levels in the strategic document on WPS in Spain from 2019. ${ }^{40}$ In case of the FAS, 6.2 per cent of the total personnel are women, a ratio which varies between 3-8 per cent per branch. According to the personnel statistics by the Spanish Ministry of Defence from 2019, the ratio of women is the lowest in the army branch, with only 3.1 per cent represented, whereas it is the highest in the Guardia Civil and the UME. Nevertheless, in the cases of the latter two, the percentage of women barely reach 8 per cent, which is below the European average. ${ }^{41}$

\section{Operation Balmis and Mission Baluarte: Spain against Covid-19}

The first wave of the Covid-19 epidemic reached Spain as early as the end of February 2020, making them one of the first European countries to face the virus, presumably due to the multiple connection points and mobility with Italy. In the light of the emergency in Italy, the Spanish Government led by Pedro Sánchez, announced the first restrictive measures in the beginning of March 2020, in parallel with the growing number of Covid-19 cases in the country. As a result, state of alarm was declared in the country, and on 15 March 2020, the largest peacetime operation within state borders of Spanish history, Operation Balmis

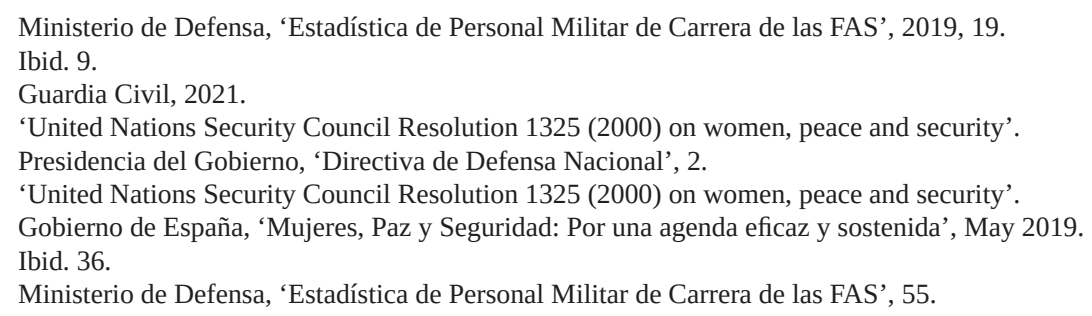


was launched to organise and conduct the intervention of the Spanish Armed Forces against the spread of the virus. ${ }^{42}$ The operation was named after Francisco Javier Balmis, a military doctor leading an overseas humanitarian expedition at the beginning of the $19^{\text {th }}$ century. ${ }^{43}$ Operation Balmis lasted a total of 98 days, and ended on 20 June 2020, during which period the Spanish Armed Forces carried out more than 20,000 interventions, more than half of which involved the disinfection of infected areas, buildings. ${ }^{44}$ Out of the total of 11,000 cases, 5,000 were performed in nursing homes and 3,500 in hospitals. ${ }^{45}$ Through Operation Balmis, the FAS helped the fight against the virus in all the provinces of Spain, as well as in more than 2,300 locations nationwide. ${ }^{46}$

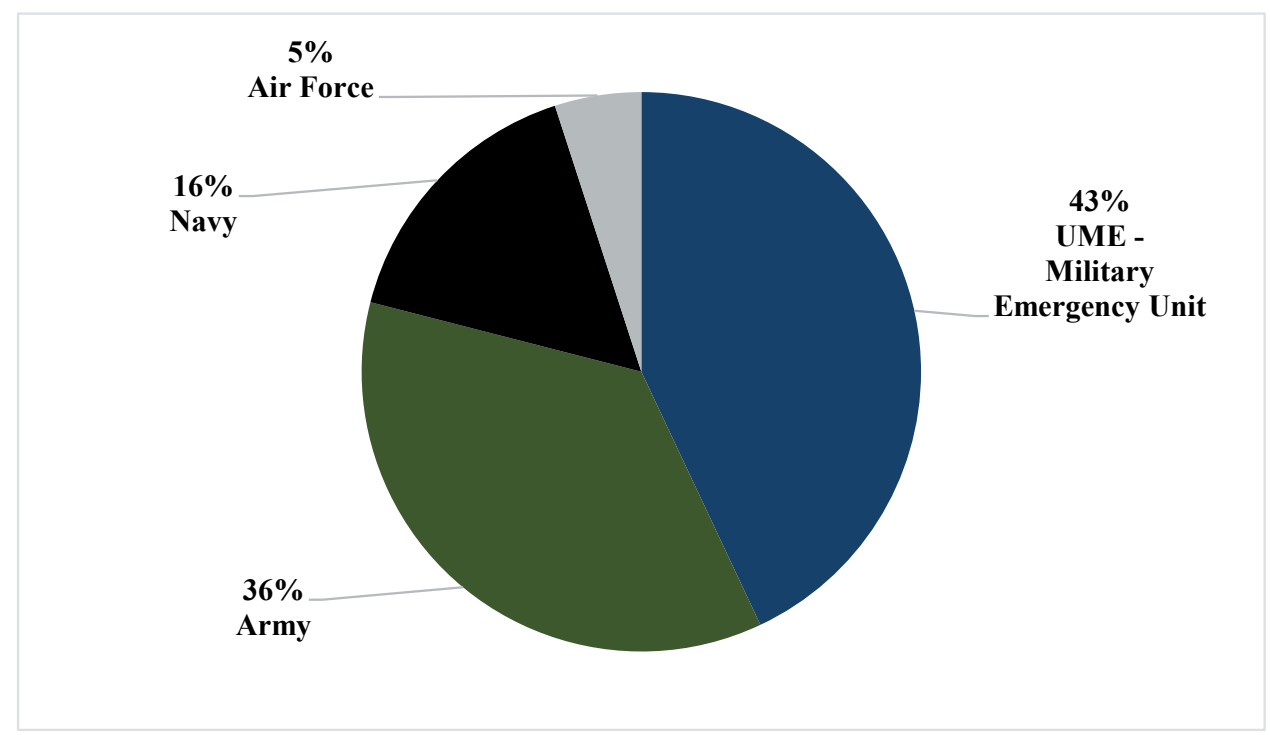

Figure 1: Percentage of the branches/units of the Spanish Armed Forces who participated in Operation Balmis

Source: Compiled by the author based on Estado Mayor de la Defensa, 'Las Fuerzas Armadas cumplen dos meses de lucha contra la COVID-19’, May 2020.

The largest percentage of troops deployed in Operation Balmis were from the Military Emergency Unit, the UME. ${ }^{47}$ The primary task of this joint special force unit established in 2005, was to intervene and provide assistance in case of national crisis, to carry out disaster management tasks, specifically in the field of natural disasters, and in other cases

42 European Parliament, 'The role of armed forces in the fight against coronavirus’, April 2020, 3.

43 Villarejo, Esteban, 'Operación Balmis: honor a la expedición militar que salvó a miles de niños en América y Filipinas’. ABC.es, 17 March 2020.

44 Infodefensa.com, 'Las cifras de la Operación Balmis: 20.000 intervenciónes en 98 días de lucha’, 27 June 2020.

45 Ibid.

46 Ibid.

47 Estado Mayor de la Defensa, 'Operation 'Balmis' deploys more than 2.500 troops in 172 cities to control COVID-19’, 24 March 2020. 
endangering the civilian population. ${ }^{48}$ In parallel with the epidemiological statistics, the largest mobilisation of the Spanish Armed Forces took place in April 2020, when 5,000 soldiers served in Operation Balmis daily as part of the fight against the Covid-19.49 According to information provided by the Spanish Ministry of Defence, 43 per cent of the military personnel deployed in Operation Balmis came from the UME, 36 per cent from the Army, 16 per cent from the Navy, and 5 per cent from the Air Force, which is illustrated in Figure 1.50

Following the completion of Operation Balmis, and a calmer period at the end of the summer, a second wave of the Covid-19 epidemic reached Europe in Autumn 2020. After the post-quarantine opening in Spain, as was typical in other EU member states as well, the society's fear of the virus decreased during the summer, and at the same time, due to the frustration of several months of closure and curfews, compliance with contact rules became a resurging problem. As a result, the Spanish Administration once again announced restrictive measures, alongside another deployment of the armed forces against Covid-19 beginning on 11 September 2020, named Mission Baluarte. ${ }^{51}$ In addition, on 24 October 2020, one of the cases of the special legal order, state of alarm was re-ordered. This time, restrictive measures were put in place for a longer period of time, but with regulations less strict than those imposed in spring 2020.52 In the last week of October 2020, the government declared a state of alarm for 15 days, which was extended a few days later with the approval of the Spanish legislation, the Congress, for a period of six months, until 9 May 2021. ${ }^{53}$ Under this form of the special legal order guaranteed by the Constitution, a night curfew was imposed, from 11 PM to 6 AM in all the provinces of the country, with the exception of the Canary Islands. ${ }^{54}$

Compared to Operation Balmis, Mission Baluarte used much more limited capabilities and personnel, and was based primarily and almost exclusively on non-armed service. In this current situation, the military forces deployed during the Mission Baluarte, soldiers from the Military Emergency Unit, the Navy, the Army and the Air Force, were tasked with operating a communications centre in cooperation with the provincial governments that continuously monitored and detected the spread of the virus. ${ }^{55}$ By 6 January 2021, a total of 750,000 Covid-19 tests had been carried out with the support of Mission Baluarte, with approximately 2,400 troops deployed. ${ }^{56}$ Another important aspect to be highlighted regarding the ongoing deployment of the FAS was that in contrast with Operation Balmis, Mission Baluerte was based on the offer of the Spanish central government to the 17 autonomous provinces of the country to help control the virus regionally. 15 out of the

\footnotetext{
48 Ministerio de Defensa, 'Unidad Militar de Emergencia'.

49 Infodefensa.com, 'Las cifras de la Operación Balmis'.

50 Estado Mayor de la Defensa, 'Las Fuerzas Armadas cumplen dos meses de lucha'.

51 Revista Española de Defensa, ‘Misión Baluarte: una defensa contra el COVID-19’, October 2020, 8.

52 El País, 'España, en alarma: el Gobierno busca que dure hasta mayo y decreta toque de queda', 25 October 2020.

53 Presidencia del Gobierno, 'Estado de Alarma’.

54 Ibid.

55 Revista Española de Defensa, ‘Misión Baluarte’, 8.

56 Ministerio de Defensa, 'Discurso de la Ministra de Defensa en la Pascua Militar’, 06 January 2021, 3.
} 
17 have accepted the military tracking units offered by Mission Baluarte of the Sanchez Government, the two who refused them were Catalonia and the Basque country. While the province of Andalucía has the largest number of soldiers deployed with the total number of 360 troops, Valencia has the lowest number with only 150 members of the Spanish Armed Forces serving through Mission Baluarte. ${ }^{57}$ Moreover, in spite of the deployment of the armed forces against the virus taking place primarily within the framework of Mission Baluarte, currently, UME, as the primary military body for crisis management, continues to be involved in the fight against Covid-19 nationwide on a day-to-day basis in different areas, such as the disinfection of critical infrastructure.

However, it is worth examining the balance of the deployment of the armed forces of Spain against the Covid-19 epidemic from a different angle, as effectiveness and success it is not determined only or exclusively by the volume, or the statistics of the defence measures taken by the Spanish Government. As an example, the nearly 100day-long domestic operation of Balmis, has shed light on several problems regarding the employment of the FAS, which were less in the crossfire of professional and political attention during peacetime. Uniformed personnel have faced not only the virus itself and its societal effects, but also factors causing hardship during the deployments and carrying out tasks. Domestic travel restrictions, frozen salaries, infrastructural and other deficiencies, as well as the lack of adequate protection of the personnel deployed were highlighted as problematic issues. ${ }^{58}$ The latter was probably the more major obstacle and was tackled by raising awareness via letters of complaint to the Spanish ombudsman, as well as the Ministry of Defence. ${ }^{59}$ The unexpectedness and severity of the epidemic thus tested not only the public health, social security and administration system, but also many aspects of homeland security and defence policy, including the command-and-control system and the rights of the military personnel.

Additionally, historic aspects of military tradition in Spain must be emphasised, which still has an enormous effect on Spanish politics, and security and defence. Spanish society, which in many cases still deliberately distance itself from the military tradition of colonisation and the Franco dictatorship (1936-1975), in the $21^{\text {st }}$ century once again found itself facing the vision of uniformed soldiers on the streets of Spain. During the interventions of the armed forces in defence of Covid-19, the daily work and efforts of the FAS soldiers became not only visible, but tangible to the Spanish population. According to a non-commissioned officer of the Army serving in Mission Baluarte, in the vast majority of cases, citizens responded positively to the calls made by the military tracking unit members when they were in touch with the civilian population: 'They receive us very well when we say that we are soldiers. ${ }^{60}$ The fight against the epidemic has thus given, and still has many long-term opportunities for Spain in terms of civil-military relations in general, and attitudes of society towards the Spanish Armed Forces. An additional example of the latter - in this case via technology and social media - was the phrase used

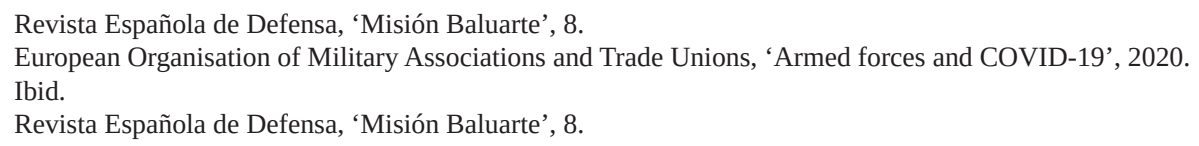


for the promotion of the fight against Covid-19 by the Ministry of Defence and the FAS in parallel with the start of Operation Balmis, 'Este vírus lo paramos unidos' [We stop this virus in unity]. ${ }^{61}$ For instance, on one of the most popular content-sharing social media application, Instagram, more than 220,000 images, photos or videos have been uploaded using this motto, connecting the deployed military personnel with the civilian citizens. ${ }^{62}$ This is just a small, yet illustrative example of the points of connection between modern technology, society and the military, which have had an impact on Spanish civil-military relations in the immediate aftermath of the deployment of the FAS against the virus.

\section{Conclusions and perspectives}

The military aspects of controlling the Covid-19 pandemic in Spain were defined by Operation Balmis and Mission Baluarte in the year of the outbreak in 2020. While the first can be apostrophised as a shorter but unprecedented domestic military operation in Spanish history in peacetime, the mandate of Mission Baluarte was much narrower, both in terms of personnel and geographical coverage. Therefore, the virus was initially tackled by the Spanish Armed Forces through a relatively shorter, but intensive, nationwide military operation with high volume mobilisation. This was followed by a tracking and monitoring mission implemented by military tracking units regionally in Spain, which were planned for a longer and more permanent nature. However, as the world is currently facing the newest variants and returning waves of Covid-19, the role of armed forces in national crisis management in parallel with the continuous mobility and visibility of military personnel in Spain seems to be becoming more and more ordinary. In the first weeks of 2021, in preparation for the third wave of the epidemic, the Spanish leadership and provincial governments decided to tighten the general rules announced until May. ${ }^{63}$ The extension of the curfew, the tightening of mask-wearing rules, and restrictions on the opening hours of restaurants all suggested that the Spanish Government was slowly re-prioritising the expansion of restrictions and ongoing preparedness one year after the outbreak. The latter may lead to changes in the role of the armed forces in the fight against the virus in 2021, as well as impacting further the civilian-military relations, development of the organisation and logistics of the armed forces, stemming from the lessons learned through primary Operation Balmis during the first wave of Covid-19.

Finally, it is worth identifying some important factors that might be of outmost importance in addition to statistical and other figures regarding the role of the FAS in controlling the virus. The deployment of troops in a special legal order in peacetime, in particular Operation Balmis, highlighted the shortcomings of infrastructure, logistics and the organisational system of the Spanish Armed Forces. In addition, other crucial elements ascended to the forefront of attention: civil-military relations, the visibility

61 Revista Española de Defensa, ‘Operación Balmis - Mision: Salvar Vidas’, May 2020.

62 Instagram, ‘\#estevirusloparamosunidos’, 2021.

63 El País, 'Toques de queda adelantados, reducción de horarios, cierres: las comunidades endurecen medidas ante el coronavirus’, 15 January 2021. 
of the military, and the societal attitudes toward the soldiers and the armed forces. The pandemic caused the FAS to become more visible, with the soldiers and their work more tangible to the citizens of a country where, due to the Franco dictatorship, many still saw the military and the uniform, as a symbol of a repressive power. ${ }^{64}$ As a lieutenant of the Spanish air force deployed during the fight against the pandemic summarised: 'We were allowed to get closer to the society, to make ourselves visible. ${ }^{\prime 65}$ The deployment of the Spanish Armed Forces in the fight against the epidemic could therefore benefit several aspects of the military, such as the social recognition and acceptance of the military profession, as well as the general public's opinion of the armed forces in the long term. Consequently, the abovementioned aspects arising from the deployment of the armed forces against the virus in Spain could help to promote a broader recognition of Spanish uniformed personnel. On the other hand, military mobility, and deployment for controlling the virus could be significant for identifying the filling of the gaps, and deficiencies which the Spanish Armed Forces face. Accordingly, force development could be the other key issue benefited by the experiences and lessons learned during 2020 regarding which some tangible outputs have been identified. The Royal Decree issued in May 2020, based on the Spanish National Security Strategy 2017 and the 2020 National Defence Directive, sought to modernise, and update the structure of the armed forces, the objectives, and priorities for their deployment, through the experience gained by the deployment of the armed forces against the Covid-19 pandemic.

\section{References}

Villarejo, Esteban, 'Operación Balmis: honor a la expedición militar que salvó a miles de niños en América y Filipinas’. ABC.es, 17 March 2020. Online: www.abc.es/espana/ abci-operacion-balmis-honor-expedicion-militar-salvo-miles-ninos-america-yfilipinas-202003170227_noticia.html

Cancio, Fernando, 'Militares contra el coronavirus: “Al servicio de los españoles”’. La Razón, 11 October 2020. Online: www.larazon.es/espana/20201011/x4gt3ww37bgunezvlt6vzfitfa. html

‘Constitución Española’, 1978. Online: www.lamoncloa.gob.es/documents/constitucion_es1.pdf

Ministerio de Defensa, ‘Legislación’, 2021. Online: https://ejercito.defensa.gob.es/personal/ legislacion_basica_defensa.html

El País, 'España, en alarma: el Gobierno busca que dure hasta mayo y decreta toque de queda’, 25 October 2020. Online: https://elpais.com/espana/2020-10-25/sanchez-aprueba-unnuevo-estado-de-alarma-para-toda-espana-con-intencion-de-que-se-prolongue-hasta-el-9de-mayo.html

${ }_{64}$ Rafael C Martínez Martínez, 'Las fuerzas armadas en España: ¿último bastión del franquismo?’, Revista Prolegómenos - Derechos y Valores 14, no 28 (2011), 103-120.

65 Fernando Cancio, 'Militares contra el coronavirus: “Al servicio de los españoles”, La Razón, 11 October 2020. 
El País, 'Toques de queda adelantados, reducción de horarios, cierres: las comunidades endurecen medidas ante el coronavirus’, 15 January 2021. Online: https://elpais.com/ sociedad/2021-01-15/toques-de-queda-adelantados-reduccion-de-horarios-cierres-lasduras-medidas-de-las-comunidades-ante-el-coronavirus.html

Estado Mayor de la Defensa, 'Las Fuerzas Armadas cumplen dos meses de lucha contra la COVID-19’, May 2020. Online: https://emad.defensa.gob.es/prensa/noticias/2020/05/ listado/200518-balance-balmis.html?__locale=es

Estado Mayor de la Defensa, 'Operation 'Balmis' deploys more than 2.500 troops in 172 cities to control COVID-19’. 24 March 2020. Online: https://emad.defensa.gob.es/en/prensa/ noticias/2020/03/listado/200324-Continuacion-Operacion-Balmis.html

Estado Mayor de la Defensa, 'Jefe de Estado Mayor de la Defensa', 2021. Online: https://emad. defensa.gob.es/emad/?_locale=es

European Organisation of Military Associations and Trade Unions, 'Armed forces and COVID-19', 2020. Online: http://euromil.org/armed-forces-and-covid-19/

European Parliament, 'The role of armed forces in the fight against coronavirus', April 2020. Online: www.europarl.europa.eu/RegData/etudes/BRIE/2020/649401/ EPRS_BRI(2020)649401_EN.pdf

Global Firepower, '2021 Military Strength Ranking’, 2021. Online: www.globalfirepower.com/ countries-listing.php

Gobierno de España, 'Mujeres, Paz y Seguridad: Por una agenda eficaz y sostenida’, May 2019. Online: www.dsn.gob.es/sites/dsn/files/MUJERES\%2C\%20PAZ\%20Y\%20 SEGURIDAD\%20\%28WEB\%29.pdf

'Guardia Civil', 2020. Online: www.guardiacivil.es/es/institucional/Conocenos/index.html Infodefensa.com, 'Las cifras de la Operación Balmis: 20.000 intervenciónes en 98 días de lucha’, 27 June 2020. Online: www.infodefensa.com/es/2020/06/27/noticia-cifrasoperacion-balmis-20000-intervenciones-lucha.html

Instagram, ‘\#estevirusloparamosunidos’, 2021. Online: www.instagram.com/explore/tags/ estevirusloparamosunidos/

International Institute for Strategic Studies, The Military Balance 2020. London: Routledge, 2021.

'Ley Orgánica 4/1981, de 1 día de junio, de los estados de alarma, excepción y sitio’. Online: www.defensa.gob.es/Galerias/defensadocs/LO-4-1981-estados-alarma.pdf

'Ley Orgánica 9/2011, de 27 de julio, de derechos y deberes de los miembros de las Fuerzas Armadas'. Online: www.boe.es/buscar/pdf/2011/BOE-A-2011-12961-consolidado.pdf

Martínez, Rafael C Martínez, 'Las fuerzas armadas en España: ¿último bastión del franquismo?' Revista Prolegómenos - Derechos y Valores 14, no 28 (2011), 103-120. Online: https:// doi.org/10.18359/prole.2381

Ministerio de Defensa, ‘Ejército de Tierra’, 2021. Online: www.defensa.gob.es/fuerzasarmadas/ et/\#

Ministerio de Defensa, ‘Estadística de Personal Militar de Carrera de las FAS’, 2019. Online: https://publicaciones.defensa.gob.es/media/downloadable/files/links/e/s/estad_stica_de_ personal_militar_de_carrera_2019.pdf

Ministerio de Defensa, ‘Estado Mayor de la Defensa’, 2020. Online: www.defensa.gob.es/ fuerzasarmadas/emad/ 
Ministerio de Defensa, ‘Unidad Militar de Emergencia', 2020. Online: www.defensa.gob.es/ ume/CONOCENOS/que-es/

Ministerio de Defensa, 'Reportajes: En primera línea’, 15 March 2020. Online: https://ejercito. defensa.gob.es/reportajes/2020/97_operacion_balmis.html

Ministerio de Defensa, ‘Estado de alarma, excepción y sitio’, 2020. Online: www.defensa.gob. es/defensa/cadenamando/situaciones/

Ministerio de Defensa, ‘Organigrama’, 2020. Online: www.defensa.gob.es/ministerio/ organigrama/

Ministerio de Defensa, 'Discurso de la Ministra de Defensa en la Pascua Militar', 06 January 2021. Online: www.defensa.gob.es/Galerias/gabinete/ficheros_docs/2021/Discurso_ Pascua_Militar_Ministra_de_Defensa_2021.pdf

Presidencia del Gobierno, 'Directiva de Defensa Nacional', 2020. Online: www.defensa.gob.es/ Galerias/defensadocs/directiva-defensa-nacional-2020.pdf

Presidencia del Gobierno, ‘Estado de Alarma’, 2020. Online: www.lamoncloa.gob.es/covid-19/ Paginas/estado-de-alarma.aspx

'Real Decreto 416/2006, de 11 de abril, por el que se establece la organización y el despliegue de la Fuerza del Ejército de Tierra, de la Armada y del Ejército del Aire, así como de la Unidad Militar de Emergencias’. Online: www.boe.es/buscar/act. php?id=BOE-A-2006-7168

'Real Decreto 521/2020, de 19 de mayo, por el que se establece la organización básica de las Fuerzas Armadas'. Online: www.defensa.gob.es/Galerias/ministerio/organigramadocs/ RD-521-2020-organizacion-basica-fuerzas-armadas.pdf

Revista Española de Defensa, ‘Operación Balmis Misión: Salvar vidas’, May 2020. Online: www.defensa.gob.es/Galerias/gabinete/red/2020/05/RED372.pdf

Revista Española de Defensa, 'Misión Baluarte: una defensa contra el COVID-19', October 2020. Online: www.defensa.gob.es/Galerias/gabinete/red/2020/10/p-6-13-red-376rastreadores.pdf

'Spanish National Security Strategy’, 2017. Online: www.dsn.gob.es/sites/dsn/files/2017_ Spanish_National_Security_Strategy_0.pdf

Statista, 'Número total de personas fallecidas a causa del coronavirus en España entre el 6 de marzo y el 4 de diciembre de 2020', 2020. Online: https://es.statista.com/ estadisticas/1104277/fallecidos-a-causa-de-covid-19-por-dia-espana/

The World Factbook, ‘Spain’. United States Central Intelligence Agency, 2021. Online: www. cia.gov/library/publications/the-world-factbook/geos/sp.html

'United Nations Security Council Resolution 1325 (2000) on women, peace and security’. Online: www.un.org/womenwatch/osagi/wps/

World Health Organization, 'WHO Director-General's opening remarks at the media briefing on COVID-19’, 11 March 2020. Online: www.who.int/director-general/speeches/detail/whodirector-general-s-opening-remarks-at-the-media-briefing-on-covid-19--11-march-2020 